AN INTERNATIONAL JOURNAL

\title{
Partition of Glucose Oxidase from Aspergillus niger in Aqueous Two-Phase Systems Based on Salt and Polyethylene Glycol
}

\author{
Jagdish Singh $^{*}$ and Neelam Verma \\ Department of Biotechnology; Punjabi University Patiala; 147002 Punjab - India
}

\begin{abstract}
The aim of this work was to study the isolation of glucose oxidase (GOx) from Aspergillus niger in aqueous two phase system consisting of PEG 7500 (150g l-1), potassium phosphate $\left(175 \mathrm{~g} \mathrm{l}^{-1}, \mathrm{~K}_{2} \mathrm{HPO}_{4}+\mathrm{KH}_{2} \mathrm{PO}_{4}\right)$ and glucose $\left(10 \mathrm{gl}^{-1}\right)$, the enzyme was partitioned in polymer phase. By sequential extraction GOx (69.2\%) was recovered in polymer phase by 11.8 fold purification, giving a yield of $129 U$ mg protein- ${ }^{l}$.
\end{abstract}

Key words: Aspergillus niger, glucose oxidase, aqueous two phase

\section{INTRODUCTION}

Glucose oxidase (EC 1.1.3.4, $\beta$-D- glucose oxygen 1 - oxidoreductase) is a flavoprotein which catalyses the oxidation of $\beta$-D- glucose by molecular oxygen to D- glucolactone and $\mathrm{H}_{2} \mathrm{O}_{2}$. It removes hydrogen from glucose and gets reduced. The reduced form of the GOx is then reoxidised by molecular oxygen and the produced hydrogen peroxide is decomposed by catalase to water and oxygen. The D-glucolactone hydrolyses spontaneously to gluconic acid (Gibson et al., 1964; Duke et al., 1969., Barker and Shirley, 1980; Doppner and Hartmeir, 1984; Crueger and Crueger, 1990).

GOx is an intracellular and extracellular and is produced on industrial scale from Aspergillus and Penicillium genus. (Pazur et al., 1965; Pazur, 1966; Muller, 1977; Van Dijken and Veenheus, 1980; Mischak et al., 1985; Visser et al., 1995;). It is widely used for the determination of glucose and commercial applications have been found in the desugaring the egg products and removing oxygen from certain food and beverages (Ward, 1967; Barker and Shirley, 1980; Pitcher, 1980 and Richter et al., 1983).

Aqueous two-phase systems (ATPS) composed of salt and soluble polymers have found widespread use in biochemical research for separation and purification of macromolecules, cells and cell particles (Albertsson et al., 1981; Walter et al., 1985). ATPS can easily be scaled- up without an appreciable change in the nature or efficiency of the process. In addition, since there is no solid phase, mixing of the two phases is possible, and hence interface transport is rapid. Very little time is required to bring most two-phase systems into equilibrium. Another benefit is that the phases are compatible with almost all the known proteins. They are an attractive alternative procedure for the separation and purification of proteins on a large scale. The question of selectivity in protein partitioning still needs to be better understood. An

\footnotetext{
* Author for correspondence: jagdish122@ rediffmail.com
} 
increased knowledge of protein behaviour in aqueous-two phase systems will also lead to the ability to predict the partitioning of specific materials (Silva and Franco, 2000). ATPS has very low tension (0.001-0.1 dyne $\left.\mathrm{cm}^{-1}\right)$ at the interpahse of polymer and salt phase which promotes mass transfer, and as a result molecules can diffuse easily from one phase to another phase. Further partition is influenced by the number of factors such as molecular weight, concentration of polymer, $\mathrm{pH}$ value and ionic strength of salt used. Today, industry demands fast and economic downsteam processes for the partitioning and purification of biomolecules with maximum recovery and purification fold. Therefore, in light of the above demands, aqueous two phase system is an ideal technology where clarification, concentration, and partial purification can be integrated in one step. Moreover, this method can be made highly selective and can be easily scaledup, thus allowing wider biotechnological applications. The present study investigated the possibility of using ATPS for the purification of GOx.

\section{MATERIALS AND METHODS}

\section{Microorganism}

A. niger (MTCC 281) was used in this study. Culture was maintained on potato dextrose agar at $4-6^{\circ} \mathrm{C}$ and sub-cultured after every 20 days.

\section{Pre-culture}

Spores of fungus A. niger $\left(7.5 \times 10^{5} / \mathrm{ml}\right)$ were grown in $250 \mathrm{ml}$ Erlenmeyer flask containing $50 \mathrm{ml}$ of the medium contains $(\mathrm{g} / \mathrm{l})$ : $\left(\mathrm{NH}_{4}\right)_{2} \mathrm{HPO}_{4}, 0.4 ; \mathrm{KH}_{2} \mathrm{PO}_{4}, 0.2 ; \mathrm{MgSO}_{4}, 0.2$; Peptone, 10; Sucrose, 70 and $\mathrm{pH}$ 5.5. This medium was incubated for $24 \mathrm{~h}$ in rotary shaker at $200 \mathrm{rpm}$ at $30{ }^{\circ} \mathrm{C}$.

\section{Composition of fermentation medium}

Fifty mille liter of the medium containing ( $\mathrm{g} / \mathrm{l})$ sucrose 75, peptone 15, $\left(\mathrm{NH}_{4}\right)_{2} \mathrm{HPO}_{4} 2$, $\mathrm{MgSO}_{4} 2, \mathrm{NaNO}_{3} 2.0, \mathrm{KCl} 0.5, \mathrm{CaCO}_{3} 20.0$ and $\mathrm{pH}$ 5.5-6.0 was inoculated with the pregerminated spores $(15 \%)$ of $24 \mathrm{~h}$ age and culture was incubated in orbital shaker $(250$ rpm) at $30{ }^{\circ} \mathrm{C}$ for $48 \mathrm{~h}$.

\section{Cell disruption}

For the breakage of cells, $5 \mathrm{~g}$ of fungal wet weight was taken in mortar and liquid nitrogen was added. After the evaporation of nitrogen, biomass was crushed to powder form and $5 \mathrm{ml}$ of sodium citrate buffer ( $\mathrm{pH} 5.75,50 \mathrm{mM})$ was added. Biomass was centrifuged at $3000 \mathrm{~g}$ for 20 minutes at $4^{0} \mathrm{C}$ and supernatant was used for further study.

\section{Enzyme assay and protein determination}

GOx activity was determined spectrophotometrically by the method of Ciucu and Petroescu, (1984) as modified by Markwell et al,(1989) method by the reduction of benzoquinone to hydroquine. One unit of GOx activity is defined as amount of enzyme which reduces $1.0 \mu \mathrm{M}$ of benzoquinone $\mathrm{ml}^{-1}$ minute ${ }^{-1}$. Protein concentration was determined using absorption method (Kirschenbaum, 1975; Kalb and Bernlohr,1977).

\section{Preparations of two phase system}

Predetermined amount of Polyethylene glycol (PEG), potassium phosphate $\left(\mathrm{KH}_{2} \mathrm{PO}_{4}\right.$ and $\mathrm{K}_{2} \mathrm{HPO}_{4}$ in different molar ration), enzyme solution and water were mixed. The contents in the tubes were mixed in centrifuge (25-50 $\mathrm{rpm}$ ) for half an hour. The top and bottom phases were withdrawn for the analysis.

\section{RESULTS AND DISCUSSION}

Effect of PEG molecular weight and concentration on the partition coefficient of GOx

Effect of different PEG molecular weight on partition behaviors was examined employing $150 \mathrm{~g} \mathrm{l}^{-1}$ PEG with different molecular weight. PEG 7500 at $30{ }^{\circ} \mathrm{C}$ and $\mathrm{pH} 5.75$ gave the maximum partitioning (1.5) of GOx to PEGrich phase. With low molecular weight PEG, there was no phase separation (Table 1). 
Table 1 - Dependence of partition coefficient of GOx on the molecular weight and concentrations of polyethylene glycol (PEG).

\begin{tabular}{|c|c|c|c|}
\hline \multicolumn{2}{|c|}{ Step 1} & \multicolumn{2}{|c|}{ Step 2} \\
\hline $\begin{array}{l}\text { Average Molecular } \\
\text { weight of PEG }\end{array}$ & $\begin{array}{l}\text { Partition coefficient } \\
(K)^{a}\end{array}$ & $\begin{array}{c}\text { Concentration of } \\
\text { PEG }\left(\mathrm{gl}^{-1}\right)^{\mathrm{c}}\end{array}$ & $\begin{array}{c}\text { Partition coefficient } \\
(\mathbf{K})^{\mathrm{a}}\end{array}$ \\
\hline 200 & -- & 100 & -- \\
\hline 400 & -- & 125 & 1.40 \\
\hline 6000 & 1.30 & 150 & 1.59 \\
\hline 75,00 & 1.59 & 200 & 1.57 \\
\hline 10,000 & 1.59 & 250 & 1.50 \\
\hline 15,000 & 1.55 & 300 & 1.50 \\
\hline
\end{tabular}

$(\mathrm{K}=$ Specific activity in polymer phase/ Specific activity in salt phase $) ;^{\mathrm{b}} \mathrm{PEG} 150 \mathrm{gl}^{-1}$, Phosphate $150 \mathrm{gl}^{-1}, \mathrm{pH}^{-7.75}$ and Temp.30 ${ }^{0} \mathrm{C}$.; ${ }^{\mathrm{C}} \mathrm{PEG} 7500$, Phosphate $\left(\mathrm{KH}_{2} \mathrm{PO}_{4}+\mathrm{K}_{2} \mathrm{HPO}_{4}\right) 150 \mathrm{gl}^{-1}$, pH 5.75 and Temp. $30{ }^{0} \mathrm{C}$

With an increase in the molecular weight of PEG, osmotic pressure of PEG phase would have decreased, which in turn increased the protein recovery to the top phase. Maximum GOx partition to polymer phase was at $15 \%$ PEG concentration at which 1.5 Partition coefficient was observed but at higher concentration GOx yield declined. This would be because decrease in the volume of PEG would have forced the GOx protein to concentrate and eventually precipitate when the limits of protein solubility were exceeded

\section{Effect of phosphate concentration and $\mathrm{pH}$ on the partition coefficient of GOx}

Partition coefficient of protein depends upon the ionic strength of medium as following equation given by the Albertson(1971):

\section{In $K p=\ln K^{0} s+(Z F / R F) \Psi---(1)$}

Where $\Psi$ is interfacial potential, $\mathrm{Z}$ is net charge on the protein, $\mathrm{R}$ is gas content, $\mathrm{F}$ is faraday constant, $\mathrm{T}$ is absulate temperature and $\operatorname{lnKp}$ is partition coefficient of protein. Interfacial potential is given by:

$$
\left.\Psi=\left\{\mathrm{RT} / \mathrm{Z}^{+}+\mathrm{Z}^{-}\right) \mathrm{F}\right\} \operatorname{In}\left(\mathrm{K}-/ \mathrm{K}^{+}\right)---(2)
$$

Where $\mathrm{K}^{-} / \mathrm{K}^{+}$is partition coefficient of protein in two phase system when $\mathrm{Z}^{+}+\mathrm{Z}^{-}$are the charge strength due to salts concentration. Change in phosphate concentarion influences the ionic strength of phase and hence partition coefficient of protein. When Phosphate concentration $\left(\mathrm{KH}_{2} \mathrm{PO}_{4}+\mathrm{K}_{2} \mathrm{HPO}_{4}\right)$ was increased from $125-175 \mathrm{gl}^{-1}$, there was increase in partition coefficient of enzyme (1.4 to 1.8 ), but above $200 \mathrm{gl}^{-1}$ concentartion there was decline in the partition coefficient (Table 2).

Different molar ratio of $\mathrm{KH}_{2} \mathrm{PO}_{4}$ and $\mathrm{K}_{2} \mathrm{HPO}_{4}$ influenced the $\mathrm{pH}$ of the two-phase system. There was maximum partition coefficient (3.67) at $\mathrm{pH}$ 6.0 and above that there was constant partition coefficient up to pH 6.5 (Fig. 1).

$\mathrm{KCl}$ and $\mathrm{NaCI}$ were also used to study the effect on the partition behavior of the protein (result not shown). $\mathrm{KCl}$ was more effective as compared to $\mathrm{NaCl}$. Different concentrations of $\mathrm{KCl}$ affected the partition coefficient and as the concentration of $\mathrm{KCl}$ was increased from $0.05-0.1 \%$, there was increase in the partition coefficient (Fig. 2).

Glucose at varying concentration $(0.05-4 \%)$ was added in the mixture and it was observed that there was maximum partition coefficient (6.44) at $0.1 \%$ and was constant upto $0.2 \%$, but above this there was slight fall in the partition coefficient (Fig.3). 
Table 2 - Effect of phosphate concentration on the partition coefficient of GOx.

\begin{tabular}{cccc}
\hline $\begin{array}{c}\text { Phosphate salt }\left(\mathbf{g l}^{-1}\right) \\
\left(\mathbf{K H}_{\mathbf{2}} \mathbf{P O}_{\mathbf{4}}+\mathbf{K}_{\mathbf{2}} \mathbf{H P O}_{\mathbf{4}}\right)^{\mathbf{a}}\end{array}$ & $\begin{array}{c}\text { Recovery of Gox in } \\
\text { Top phase }(\boldsymbol{\%})\end{array}$ & $\begin{array}{c}\text { Recovery of protein in } \\
\text { top phase } \mathbf{\%})\end{array}$ & $\begin{array}{c}\text { Partition coefficient } \\
(\mathbf{K})\end{array}$ \\
\hline 125 & 59 & 25 & 1.40 \\
150 & 64 & 24 & 1.59 \\
175 & 69 & 24 & 1.80 \\
200 & 69 & 26 & 1.70 \\
250 & 58 & 29 & 1.70 \\
300 & 52 & 29 & 1.70 \\
\hline
\end{tabular}

PEG $7500\left(150 \mathbf{g l}^{-1}\right), \mathrm{pH} 5.75$ and Temp. $30^{\circ} \mathrm{C}$.

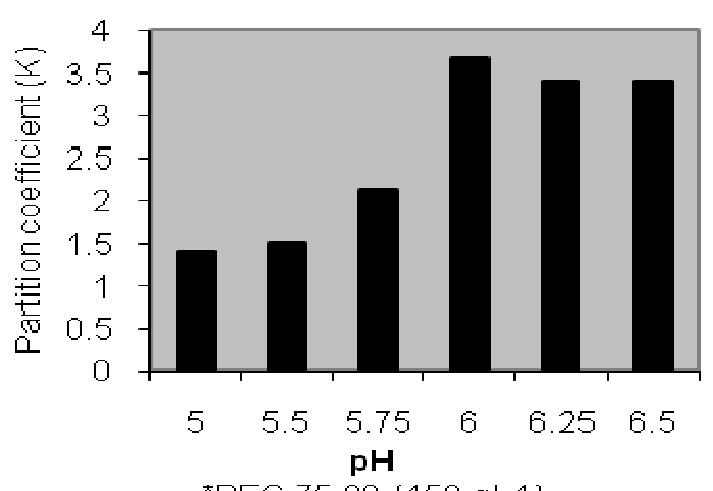

*PEG $7500(150 \mathrm{gl}-1)$

Figure 1 - Dependences of partition coefficient* of Gox on the pH of Phase system.

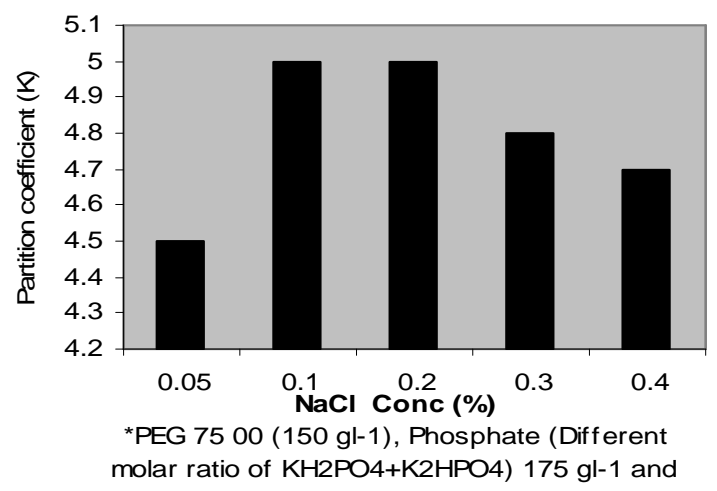

Figure 2 - Effect of $\mathrm{NaCl}$ concentrations on the partition behavior** of GOx in two phase system. 


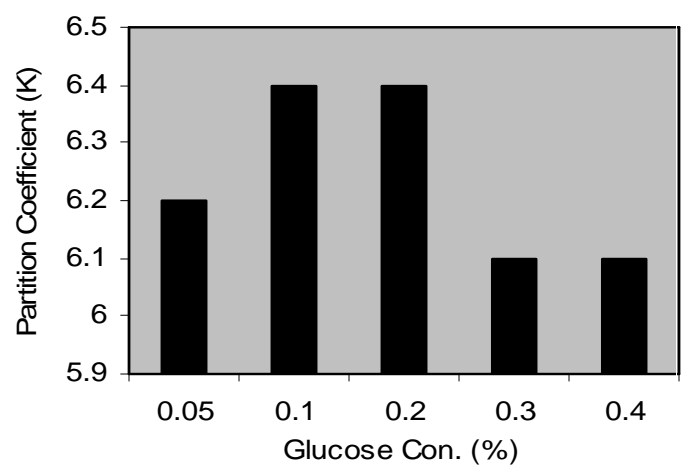

Figure 3 - Effect of Glucose concentration on the partition behaviors of GOx in two phase system.

Effect of temperature on the partition coefficient of Gox

The effect of temperature on the partition coefficient of Gox was studied (Table 3).

The results showed a increase of $\mathrm{K}$ with temperature and maximum partition coefficient (6.9) at temperature $35^{\circ} \mathrm{C}$. At $40^{\circ} \mathrm{C}$ there was sharp decline. The effect of temperature is quite complex because the phase composition, electrostatic interactions and hydrophobic interactions are all coupled to the temperature. In addition, the proteins can undergo denaturation, conformational changes, and self association or dissociation when the temperature is raised. Some reports have described an increase in the partition coefficient with the temperature (Diamond and Hsu, 1992; Forciniti et al., 1991) others have found that the partition coefficient showed no temperature dependence.

Table 3 - Dependences of partition coefficient of GOx on the temperature of Phase system.

\begin{tabular}{cccc}
\hline $\begin{array}{c}\text { Temperature } \\
\left({ }^{\mathbf{C}} \mathbf{C}\right)\end{array}$ & $\begin{array}{c}\text { Specific activity of top } \\
\text { phase (PEG phase })\end{array}$ & $\begin{array}{c}\text { Specific activity of Bottom } \\
\text { phase(Salt phase })\end{array}$ & $\begin{array}{c}\text { Partition coefficient } \\
(\mathbf{K})\end{array}$ \\
\hline 25 & 20 & 3.27 & 6.1 \\
30 & 21 & 3.2 & 6.5 \\
35 & 21.5 & 3.16 & 6.8 \\
40 & 19 & 3.3 & 5.6 \\
\hline
\end{tabular}

${ }^{\mathrm{a}}$ PEG $7500\left(150 \mathbf{g l}^{-1}\right)$, Phosphate $175 \mathbf{g l}^{-1}, \mathrm{pH} 6.0, \mathrm{KCl} .0 .2 \%$ and Glucose $0.1 \%$.

\section{REFERENCES}

Albertsson, P. A., Johansson, G. and Tjerneld, F. (1991), Aqueous two phase separations. In Separation processes in Biotechnology, J. A. Asenjo (eds.). New York and Basel: Marcel Dekker, Inc. pp. 287- 327.

Barker, S. A. and Shirley, J. A. (1980), Glucose oxidase, Glucose dehydrogenase, Glucose isomerase, $\beta$-Galactosidase and Invertase. In Microbial Enzymes and Bioconversion, A. H. Rose (eds.). San Francisco, London New York, Toronto and Sydney: Academic Press. pp. 173- 226.

Ciucu, A. and Patroescu, C. (1984), Fast Spectrophotometric methods of determining the activity of glucose oxidase. Anal. Lett., 17, 14171427.
Crueger, A. and Crueger, W. (1990), Glucose transforming Enzymes. In Microbial Enzyme and Biotechnology, 2nd, ed, W. M. Fogarty and C. T. Kelly (eds.). London and New York: Elsevier Applied Sciense Publishers. pp. 177-226.

Diamond, A. D. and Hsu, J. T. (1992), Aqueous two phase systems for biomolecule separation. Adv.Biochem. Eng., 47, 89-135.

Doppner, T. and Hartmeir, W. (1984), Glucose oxidation by modified mould mycelium. Starch/Strake., 36, 283-287.

Duke, F. R., Weibel, M., Phage, D. S., Bulgrin, V. C. and Luthy, J. (1969) The glucose oxidase mechanism, Enzyme activation by substrate. J. Amer. Chem. Soci., 91, 3904-3909. 
Forciniti, D., Hall, C. K. and Kula, M. R. (1991), Temperature dependence of the partition coefficient of proteins in aqueous two-phase systems. Bioseparation ., 2, 115-128.

Gibson, Q. H., Swoboda, B. E. P. and Massey, V. (1964), Kinetics and Mechanism of action of glucose oxidase. Biol.Chem., 239, 3927-3934.

Kalb, V. F. and Bernlohr, R. W. (1977), A new spectrophotometric assay for protein in cell extracts. Anal. Biochem., 82, 362-371.

Kelley, R. L. and Reddy, C. A. (1986), Purification and characterization of glucose oxidase from Ligninolytic culture of Phanerochaete chrysosporium. J. Bacteriol., 166(1), 269-274.

Kim, K. K., Fravel, D. R. and Papavizas, G. C. (1990), Production purification and properties of glucose oxidase from biocontrol fungus Talaromyces flavus. Can. J. Microbiol., 36, 199-205.

Kirschenbaum, D. M. (1975), Molar absorptvity and and $\mathrm{A} 1 \% / 1 \mathrm{~cm}$ values for proteins at selected wavelengths of the ultraviolet and visible regions. Anal. Biochem., 68,465-484.

Markwell, J., Frakes, L. G., Brott, E. C., Osterman, J. and Wagner, F. W. (1989), Aspergillus niger mutants with increased glucose oxidase production. Appl. Microb. Biotechnol., 30, 166-169.

Mischak, H., Kubicek, C. P. and Rohar, M. (1985), Formation and location of glucose oxidase in citric acid producing mycelia of Aspergillus niger. J. Appl. Microb. Biotechnol., 21,27-31.

Pazur, J. H., Kleppe, K. and Cepure, A. (1965), A glycoprotein structure for glucose oxidase from Aspergillus niger. Arch. Biochem. Biophys., 11, 351357.
Pazur. J. H. (1966), Glucose oxidase from Aspergillus niger. Meth. Enzymol., 9, 82-87.

Pitcher, W. H. (1980), Immobilized enzymes for food processing. New York: CRC Press.

Richter, G. (1983), Glucose oxidase In: Industrial enzyymology: The application of enzymes in industry, T. Golfrey and J. R. Reichelt (eds.). New York: The Nature Press. pp. 428-436.

Silva, M. E. and Franco, T. T. (2000), Liquid-liquid extraction of biomolecules in downstream processing - a review paper. Braz. J. Chem. Eng., 17, 1-30.

Van Dijken, J. P. and Veenheus, M. (1980), Cytochemical localization of glucose oxidase in peroxisome of Aspergillus niger. Eur. J. Appl. Microb. Biotechnol., 9, 275-283.

Visser, J., Bussink, H. J. and Witteveen, C. (1995), Gene expression in filamentous fungi. Expression of pectinases and glucose oxidase in Aspergillus niger. Bioprocess Technol., 22, 241-245.

Walter, H., Brooks, D. E. and Fisher, D. (1985) Partitioning in Aqueous Two-Phase Systems: Theory,Methods, Uses, and Applications to Biotechnology. Orlando : Academic Press. Received: April 28, 2003; Revised: September 30, 2003; Accepted: February 06, 2004

Ward, G. E. (1967), Production of gluconic acid, glucose oxidase, fructose, Sorbose. In Microbial Technology, H. J. Peppler (eds.). New York: Reinhold Publishing Corporation. pp. 200-221.

Received: November 28, 2007; Revised: May 15, 2008; Accepted: April 13, 2010. 